University of Nebraska - Lincoln

DigitalCommons@University of Nebraska - Lincoln

Faculty Papers and Publications in Animal

Science

Animal Science Department

2002

Dried Poultry Waste for Cows Grazing Low-Quality Winter Forage

D. J. Jordon

University of Nebraska-Lincoln

Terry J. Klopfenstein

University of Nebraska-Lincoln, tklopfenstein1@unl.edu

Don C. Adams

University of Nebraska-Lincoln, dadams1@unl.edu

Follow this and additional works at: https://digitalcommons.unl.edu/animalscifacpub

Part of the Animal Sciences Commons

Jordon, D. J.; Klopfenstein, Terry J.; and Adams, Don C., "Dried Poultry Waste for Cows Grazing LowQuality Winter Forage" (2002). Faculty Papers and Publications in Animal Science. 539.

https://digitalcommons.unl.edu/animalscifacpub/539

This Article is brought to you for free and open access by the Animal Science Department at DigitalCommons@University of Nebraska - Lincoln. It has been accepted for inclusion in Faculty Papers and Publications in Animal Science by an authorized administrator of DigitalCommons@University of Nebraska - Lincoln. 


\title{
Dried poultry waste for cows grazing low-quality winter forage ${ }^{1}$
}

\author{
D. J. Jordon, T. J. Klopfenstein ${ }^{2}$, and D. C. Adams \\ Department of Animal Science, University of Nebraska, Lincoln 68583-0908 \\ and University of Nebraska, North Platte 69101
}

\begin{abstract}
Two trials conducted in 1996-97 measured BW and body condition score changes of cows fed different sources of degradable intake protein, including dried poultry waste and soybean meal, while grazing low-quality winter forages. In Trial 1, 60 springcalving cows (5 yr; $555 \mathrm{~kg}$ ) were used in an individual supplementation trial. Cows were gathered three times a week, sorted into individual pens, and fed their respective supplement. Cows grazed dormant native Sandhills winter range (common pasture) and were assigned to one of six supplemental treatments: 1) no supplement, 2) urea, 3) $22 \%$ dried poultry waste + urea, 4) soybean meal, 5) $22 \%$ dried poultry waste + soybean meal, or 6) $44 \%$ dried poultry waste. All supplements were based on wheat middlings and soybean hulls and were formulated to contain $44 \% \mathrm{CP}$. Thirty-six cows were selected randomly (six per treatment) for a 5-d measurement of forage intake from December 16 through December 20, 1996. Cows receiving supplements gained more weight $(P<0.001)$ and maintained
\end{abstract}

greater body condition $(P<0.001)$ than unsupplemented cows. Cows receiving urea gained less $(P<0.10)$ than cows receiving a source of natural protein, but body condition remained similar. No differences were found in daily forage or total organic matter intake $(P$ $>0.10$ ). In Trial 2 , cows grazed corn residues. Fortyeight spring-calving cows were group-fed supplements in one of six 4-ha paddocks. Cows received supplements containing either soybean meal or dried poultry waste that were the same as the soybean meal and $44 \%$ dried poultry waste supplements fed in Trial 1 ; gains were not different $(P>0.10)$. Under the economic conditions that existed at the time of these experiments, the supplement containing dried poultry waste resulted in a savings of $\$ .04$ per cow per day and a total savings of $\$ 3.20$ per cow over an 80 -d period. Feeding a supplement containing dried poultry waste resulted in performance similar to that when feeding a more conventional supplement containing soybean meal.

Key Words: Beef Cows, Soyabean Oilmeal, Wastes

(C)2002 American Society of Animal Science. All rights reserved.

J. Anim. Sci. 2002. 80:818-824

\section{Introduction}

Cornstalks and winter range typically are utilized by producers in the Midwest and Central Great Plains as low-cost winter feed. However, grazed winter forages are often deficient in degradable intake protein (DIP) and do not meet the metabolizable protein requirements of cows. Rock et al. (1991) showed that cows grazing cornstalks did not respond to protein sources with graded amounts of undegradable intake protein (UIP). Likewise, Karges (1990) determined that UIP was not limiting in gestating beef cows fed native range hay. Therefore, a cheap source of DIP may be all that is required to sufficiently maintain cows through the

\footnotetext{
${ }^{1}$ Published with the approval of the director as paper no. 13272 , journal series, Nebraska Agric. Res. Div.

${ }^{2}$ Correspondence: C220 Animal Science (phone: 402-472-6443; fax: 402-472-6362; E-mail: tklopfenstein1@unl.edu).

Received April 16, 2001.

Accepted October 30, 2001.
}

winter. Dried poultry waste (DPW) is obtained primarily from caged laying hens and is free of bedding. Dried poultry waste contains approximately $28 \%$ protein and 26 to $30 \%$ ash (Bhattacharya and Taylor, 1975). Approximately $50 \%$ of the $\mathrm{N}$ in poultry droppings is in the form of uric acid N. Oltjen et al. (1968) found that uric acid was degraded to ammonia by rumen microorganisms more slowly than urea. The slower degradation might lead to a more favorable rumen ammonia pattern for efficient $\mathrm{N}$ utilization in high-forage diets. In addition, DPW is an excellent source of calcium, phosphorus, potassium, iron, and zinc (NRC, 1984), which may help to further reduce winter supplementation costs.

The objective of the present trials was to determine whether dried poultry waste could replace soybean meal (SBM) for cows grazing low-quality winter forages.

\section{Materials and Methods}

\section{Trial 1}

Sixty crossbred (1/4 Angus, 1/4 Hereford, 1/4 Simmental, and 1/4 Gelbvieh), 5-yr-old, gestating (average 
Table 1. Supplement ${ }^{\mathrm{a}}$ composition for Trials 1 and 2

\begin{tabular}{|c|c|c|c|c|c|}
\hline \multirow[b]{2}{*}{ Ingredient } & \multicolumn{5}{|c|}{ Supplement $(\% \text { of DM })^{\mathrm{b}}$} \\
\hline & Urea $^{c}$ & $22 \% \mathrm{DPW}+\mathrm{Urea}^{\mathrm{c}}$ & $\mathrm{SBM}^{\mathrm{cd}}$ & $22 \% \mathrm{DPW}+\mathrm{SBM}^{\mathrm{c}}$ & $\mathrm{DPW}^{\mathrm{cd}}$ \\
\hline Wheat middlings & 27.1 & 18.4 & 8.26 & 9.19 & 8.22 \\
\hline Soybean hulls & 27.1 & 18.4 & 8.26 & 9.19 & 8.22 \\
\hline Feather meal & 23.6 & 24.8 & 11.5 & 18.8 & 26.3 \\
\hline Dried poultry waste & - & 22.0 & - & 22.0 & 44.0 \\
\hline Urea & 3.44 & 1.7 & - & - & - \\
\hline Soybean meal $(47 \% \mathrm{CP})$ & - & - & 54.5 & 26.9 & - \\
\hline Molasses & 4.0 & 4.0 & 4.0 & 4.0 & 4.0 \\
\hline Tallow & 2.0 & 2.0 & 2.0 & 2.0 & 2.0 \\
\hline Salt & 2.64 & 2.30 & 2.88 & 2.41 & 1.94 \\
\hline Dicalcium phosphate & 2.5 & 0.42 & 2.06 & 0.21 & - \\
\hline Potassium chloride & 1.3 & 0.61 & - & - & - \\
\hline Copper sulfate & 0.038 & 0.056 & 0.036 & 0.034 & 0.033 \\
\hline Limestone & 1.0 & - & 1.16 & - & - \\
\hline Zinc sulfate & - & - & 0.044 & 0.021 & - \\
\hline Vitamin A, D, E & 0.25 & 0.25 & 0.25 & 0.25 & 0.25 \\
\hline Ameribond $^{\mathrm{e}}$ & 5.0 & 5.0 & 5.0 & 5.0 & 5.0 \\
\hline \multicolumn{6}{|l|}{ Protein analysis } \\
\hline $\mathrm{CP}, \%$ & 45.9 & 44.1 & 43.1 & 44.9 & 44.2 \\
\hline $\mathrm{UIP}, \%$ of $\mathrm{CP}^{\mathrm{f}}$ & 50.0 & 50.0 & 50.0 & 50.0 & 50.0 \\
\hline
\end{tabular}

calving date was March 30, 1997) beef cows (555 kg) were assigned randomly to one of six supplemental treatments (10 cows/treatment): 1) no supplementation, 2) urea, 3) $22 \% \mathrm{DPW}$ + urea, 4) SBM, 5) $22 \% \mathrm{DPW}$ + SBM, and 6) 44\% DPW (Table 1). Supplements were formulated to contain $44 \% \mathrm{CP}, 1.2 \% \mathrm{Ca}, 1.0 \% \mathrm{P}, 1.5 \%$ $\mathrm{K}$, and equal amounts of DIP, and feather meal was added in varying amounts to equalize UIP. Additionally, all supplements were cubed $(2.2 \mathrm{~cm})$. Cows grazed in a common pasture of dormant native range at the University of Nebraska Gudmundsen Sandhills Laboratory near Whitman, $\mathrm{NE}$ (160 ha; 1.73 animal unit months/ha) and were individually supplemented for $106 \mathrm{~d}$ from November 19, 1996, through March 4, 1997. Cows were individually offered $0.85 \mathrm{~kg}$ (DM basis) of supplement in plastic tubs on Monday and Wednesday and $1.3 \mathrm{~kg}$ (DM basis) on Friday. Cows were gathered from the pasture, sorted into individual pens, and fed the assigned supplement. Cows on the control treatment were sorted off and returned to the pasture. Cows readily consumed supplements in several minutes. All animals had free access to salt and limestone. One animal on the $44 \%$ DPW treatment refused to consume supplement throughout the trial. Subsequently, all performance and intake data from that particular animal were removed from the analysis.

Average ambient temperature and wind speed were $-4^{\circ} \mathrm{C}$ and $2.3 \mathrm{~km} / \mathrm{h}$, respectively. Average high and low temperatures were 3 and $-11^{\circ} \mathrm{C}$, respectively.

The predominant grass species in the pasture were little bluestem (Schizachyrium scoparium [Michx.]
Nash.), prairie sandreed (Calamovilfa longifolia [Hook] Scribn.), sand bluestem (Andropogon hallii Hack.), switchgrass (Panicum virgatum L.), and blue gamma (Bouteloua gracilis H.B.K. Lag ex Steud.; Perez, 1991). Predominant forbs and shrubs were western ragweed (Ambrosia psilostachya D.C.) and leadplant (Amorpha canescens [Nutt.] Pursh).

Forage intake by 36 cows (six cows/treatment) was measured for $5 \mathrm{~d}$ from December 16 through December 20,1996 . Each cow was orally dosed with an intraruminal continuous chromium (Cr)-releasing device (Captec Pty. Ltd., Australia) $5 \mathrm{~d}$ prior to the 5-d fecal collection to determine fecal DM output. Three to five hundred grams of feces was collected from the rectum of each cow daily at approximately 0800 . Forage intake was determined by dividing fecal output by in vitro organic matter indigestibility of the forage diet after accounting for supplement (Hollingsworth-Jenkins et al., 1996).

Five steers were used in a total fecal collection to validate the release rate of the Cr bolus from December 16 through December 20, 1996. Steers were dosed with intraruminal continuous Cr-releasing devices, from the same manufacturer's production batch as those administered to cows. Each steer was fitted with a fecal collection bag for total fecal collection to determine a correction factor for fecal output (Hollingsworth et al., 1995). Steers were gathered once daily from the same pasture that contained the cows, and fecal bags were removed, emptied, and replaced on the steers. Feces were then weighed, mixed, subsampled (300 to $500 \mathrm{~g}$ ), and frozen for later analysis. In addition, a rectal grab sample 
was collected and frozen for subsequent analysis of $\mathrm{Cr}$. Steers did not receive any supplement during the collection period. Hollingsworth et al. (1995) reported that protein supplementation did affect payout under conditions similar to these. Chromium output as determined by the manufacturer was $1,500 \mathrm{mg}$ chromic oxide/d, or $1,022 \mathrm{mg} \mathrm{Cr} / \mathrm{d}$. Based on samples collected from the steers, it was determined that actual payout of the bolus was $27.84 \%$ of the manufacturer's claim.

Forage samples were collected one time during the intake period from six esophageally fistulated cows (568 $\mathrm{kg}$ ). Cows had been fistulated for 3 to $5 \mathrm{yr}$ previously as described by Adams et al. (1991) with modifications for adult cattle. Surgical preparation and postsurgical care were reviewed and approved by the University of Nebraska Institutional Animal Care and Use Committee. Cows were held off feed overnight then placed in the pasture and allowed 20 to $30 \mathrm{~min}$ for diet collection. Masticate samples were collected in screen-bottomed bags and frozen for subsequent analysis.

Average ambient temperature and wind speed during the diet collection period were $-11^{\circ} \mathrm{C}$ and $20.7 \mathrm{~km} / \mathrm{h}$, respectively. On the $2 \mathrm{~d}$ prior to esophageal diet collections the average low temperature was $-24^{\circ} \mathrm{C}$ and the average wind speed was $15.1 \mathrm{~km} / \mathrm{h}$.

All fecal and extrusa samples were stored frozen until analyses were performed. Fecal samples were freezedried and ground to pass through a 1-mm screen in a Wiley Mill and composited by animal. Fecal output was determined from the concentration of $\mathrm{Cr}$ in the composited samples. Fecal samples were analyzed for chromium by atomic absorption spectrophotometry using an air-plus-acetylene flame (Williams et al., 1962). Extrusa samples were freeze-dried and ground to pass through a 2-mm screen for determination of protein degradability. A subsample of the extrusa sample ground through the 2-mm screen was later ground through a 1-mm screen for dry matter, organic matter, crude protein, and in vitro organic matter disappearance (IVOMD) analysis. Dry matter and organic matter were determined by standard methods (AOAC, 1990). Crude protein was analyzed by the combustion method (AOAC, 1996) using a nitrogen analyzer (Perkin-Elmer, Norwalk, CT). In vitro organic matter disappearance was determined by modified procedures of Tilley and Terry (1963). Samples were incubated for $48 \mathrm{~h}$ in 50:50 ruminal fluid and McDougall's solution (McDougall, $1948)$ at $39^{\circ} \mathrm{C}$ followed by 24 -h pepsin digestion. Two donor animals, one fed grass hay and another fed a corn cob diet containing soybean meal, were used for fluid collection. Fluid was collected via rumen fistula from each steer approximately $16 \mathrm{~h}$ after feeding and mixed in a 50:50 ratio. Undegraded intake protein was estimated using an in situ incubation of extrusa samples in Dacron bags (Ankom, Fairport, NY) for 2 and $12 \mathrm{~h}$ in three separate incubation runs over $3 \mathrm{~d}$ as described by Mass et al. (1996) using the same fistulated steers used for in vitro rumen fluid collections.
Initial and final weights were determined by taking the average of two consecutive days' weights at the beginning and end of the trial. Initial weights were obtained on November 18 and 19, 1996. Final weights were taken on March 3 and 4, 1997. In addition, a 1-d midpoint weight (January 10, 1997) was collected. Body condition scores (BCS; 1 thinnest to 9 fattest) according to the system described by Richards et al. (1986) were determined by palpation of the ribs and thoracic vertebrae on the same days body weights were measured. One technician (blind to treatments) was used for BCS determination. Individual calf birth weights were obtained within 24 to $48 \mathrm{~h}$ after birth.

\section{Trial 2}

Forty-eight spring-calving cows (6 yr, $592 \mathrm{~kg}$ ) in midgestation (average calving date of April 1, 1997) were allotted randomly to six groups and assigned to one of two winter supplement treatments with three replications/treatment. Cows continuously grazed an irrigated cornstalk field divided into six 4-ha paddocks (eight cows/paddock) with a stocking rate of two cows/hectare. Cows grazed fields from November 5, 1996, through January 8, 1997 (65 d), at the University of Nebraska Agricultural Research and Development Center, Ithaca, Nebraska. Cows were group-fed cubed $(2.2 \mathrm{~cm})$ supplements once daily in temporary bunks and received 0.53 per cow (DM basis). Treatments were 1) SBM and 2) 44\% DPW. Supplements were the same as those described for treatments 4 (SBM) and $5(44 \%$ DPW) in Trial 1 (Table 1). One animal on the 44\% DPW treatment refused to consume supplement throughout the trial. Subsequently, all performance data for that particular animal were removed from the analysis.

Both initial and final weights were the average of two consecutive days' weights following $3 \mathrm{~d}$ of limit feeding a 50:50 mixture of grass hay and corn bran at $2 \%$ of body weight. Initial weights were collected on November 4 and 5, 1996. Final weights were obtained on January 7 and 8, 1997. Cows were removed from fields when, based on visual appraisal, the quantity of forage (leaf and husk from the corn plant) became limiting to animal performance.

Average ambient temperature and wind speed during the trial were $-3^{\circ} \mathrm{C}$ and $13.3 \mathrm{~km} / \mathrm{h}$, respectively. Average high and low temperatures were 1.5 and $-8^{\circ} \mathrm{C}$, respectively.

\section{Statistical Analysis}

Performance and intake data from Trial 1 were analyzed as a completely randomized design using the GLM procedure of SAS (SAS Inst. Inc., Cary, NC). Cow was the experimental unit and the model included treatment. Five preplanned orthogonal single degree of freedom contrasts (Table 2) were also included in the analysis (Steel and Torrie, 1980). Significant differences were noted at $P<0.10$. 
Table 2. Single degree of freedom contrasts included in the statistical analysis for Trial 1

Trial 1 contrasts $^{\mathrm{a}}$

Control vs Urea, DPW + Urea, SBM, DPW + SBM, and DPW

Urea vs DPW + Urea, SBM, DPW + SBM, DPW

$\mathrm{SBM}$ vs $\mathrm{DPW}+$ Urea, $\mathrm{DPW}+\mathrm{SBM}, \mathrm{DPW}$

$\mathrm{DPW}$ vs DPW + Urea, DPW + SBM

$\mathrm{DPW}+$ Urea vs DPW + SBM

${ }^{a} \mathrm{DPW}=$ dried poultry waste; $\mathrm{SBM}=$ soybean meal.

Data from Trial 2 were analyzed as a completely randomized design using the GLM procedure of SAS (SAS Inst. Inc.). Paddock was the experimental unit, and the model included treatment.

\section{Results and Discussion}

\section{Trial 1}

Esophageally fistulated cows consumed diets that contained $6.8 \% \mathrm{CP}$ (DM basis), of which 0.55 percentage units was UIP (DM basis). Crude protein values are above and UIP values are below those previously reported for similar native Sandhills winter range (Hollingsworth-Jenkins et al., 1996). Also, Downs (1997) reported lower $\mathrm{CP}$ values for cows grazing similar range over the same time period of 1996, indicating that the present values are above what is typically found. In vitro organic matter disappearance of diets collected by esophageally fistulated cows was $48.5 \%$, which is below IVOMD values typically seen (50 to $52 \%$ ) on native Sandhills winter range (Downs, 1997; Lardy, 1997). One possible explanation for the outlying values could be the weather conditions present during diet collections. A total of three diet collections were originally planned during the same week fecal collections were to be made (December 16 through December 20, 1996). However, extremely cold conditions persisted throughout the week (temperature $=-10$ to $-20^{\circ} \mathrm{C}$; average windspeed $=20 \mathrm{~km} / \mathrm{h}$ ), allowing for only one diet collection. Another possible reason is that the diet sample was collected relatively early in the trial, which may have contributed to the outlying values.

Cows consuming supplement gained more weight (Table 3) and maintained higher body condition scores (Table $4 ; P<0.001$ ) than unsupplemented cows. Average treatment BCS at the beginning of the trial ranged from 5.0 to 5.2 and was maintained through at least d 53 of the trial. By the end of the trial, the BCS of supplemented cows averaged 4.3, whereas unsupplemented cows had an average BCS of 3.9. HollingsworthJenkins et al. (1996) showed that cows may respond positively to DIP supplementation on native Sandhills winter range, indicating the range grass was deficient in DIP. Using the NRC (1996) computer model (level I; $10 \%$ microbial efficiency) with diet quality values obtained from esophageally collected diets from this trial $(6.8 \% \mathrm{CP}, 0.55 \% \mathrm{UIP}$, and $48.5 \%$ IVOMD), cows consuming no supplement received sufficient DIP from the forage and should have lost $1 \mathrm{BCS}$ in approximately $115 \mathrm{~d}$. Unsupplemented cows in this trial lost 1.3 BCS in $53 \mathrm{~d}$ (last half of the trial). This discrepancy may indicate two things. First, as discussed previously, CP values from the present trial were higher than expected, and UIP and IVOMD values were lower than expected. Perhaps the diet sampling, based on only one collection period and combined with the weather conditions, was insufficient to accurately describe the forage. Additionally, the diet samples for the present trial were collected early in the grazing period, which likely did not allow an accurate assessment of the forage quality later in the trial. The animal performance data support this conclusion. No animal (either supplemented or unsupplemented) lost BCS during the first half of the trial. All of the BCS was lost in the second half, when it would be expected that diet quality would decline below our values. Patterson et al. (2000) collected $2 \mathrm{yr}$ of winter diet samples on similar range (at the same ranch) and found that forage quality values averaged $5.78 \%$ (CP), $1.48 \%$ (UIP), and $49.5 \%$ (IVOMD). Using the forage quality values obtained by Patterson et al. (2000), 11.6 $\mathrm{kg}$ intake, $10 \%$ microbial efficiency, $0^{\circ} \mathrm{C}$ temperature, and $16.1 \mathrm{~km} / \mathrm{h}$ windspeed, the NRC (1996) computer model (level I) predicts that supplemented cows should have lost 1 BCS in $52 \mathrm{~d}$; actual data from this trial show that cows lost $1 \mathrm{BCS}$ in $53 \mathrm{~d}$. Obviously, the use of these values results in an assessment that agrees closely with the actual performance data. The model predicts that the forage supplied $498 \mathrm{~g}$ of DIP/d and $572 \mathrm{~g} / \mathrm{d}$ was required. Additionally, $503 \mathrm{~g}$ of UIP was supplied/d and $591 \mathrm{~g} / \mathrm{d}$ was required. Supplements all supplied about $100 \mathrm{~g} / \mathrm{d}$ of each DIP and UIP. No differences were found in calf birth weights (Table 3 ) between supplemented and unsupplemented cows, indicating that despite the DIP deficiency of the control animals, they were able to maintain fetal growth comparable to that of supplemented animals. Lamm et al. (1977) also found no differences in calf birth weights despite depressed performance when cows were supplemented with $0.11 \mathrm{~kg}$ crude protein equivalent (CPE) daily compared with cows supplemented with $0.23 \mathrm{~kg} \mathrm{CPE}$ daily.

Cows consuming natural protein supplements had higher ADG $(P<0.10$; Table 3$)$ than cows fed urea. These results are in agreement with those of Oltjen and Dinius (1976), who reported that steers fed forage diets and supplemented with DPW gained more BW than steers fed the same forage diet supplemented with NPN from various sources. Natural protein may be important as a source of amino acids to be utilized by the microbial population, and protein may have a slower rate of nitrogen release than urea, thereby complementing the relatively slow rate of winter forage digestion. Oltjen et al. (1968) found that uric acid was degraded to ammonia by microorganisms more slowly than urea, suggesting a more favorable ruminal ammonia pattern 
Table 3. Weight change of cows fed different sources of degradable intake protein grazing native Sandhills winter range (Trial 1)

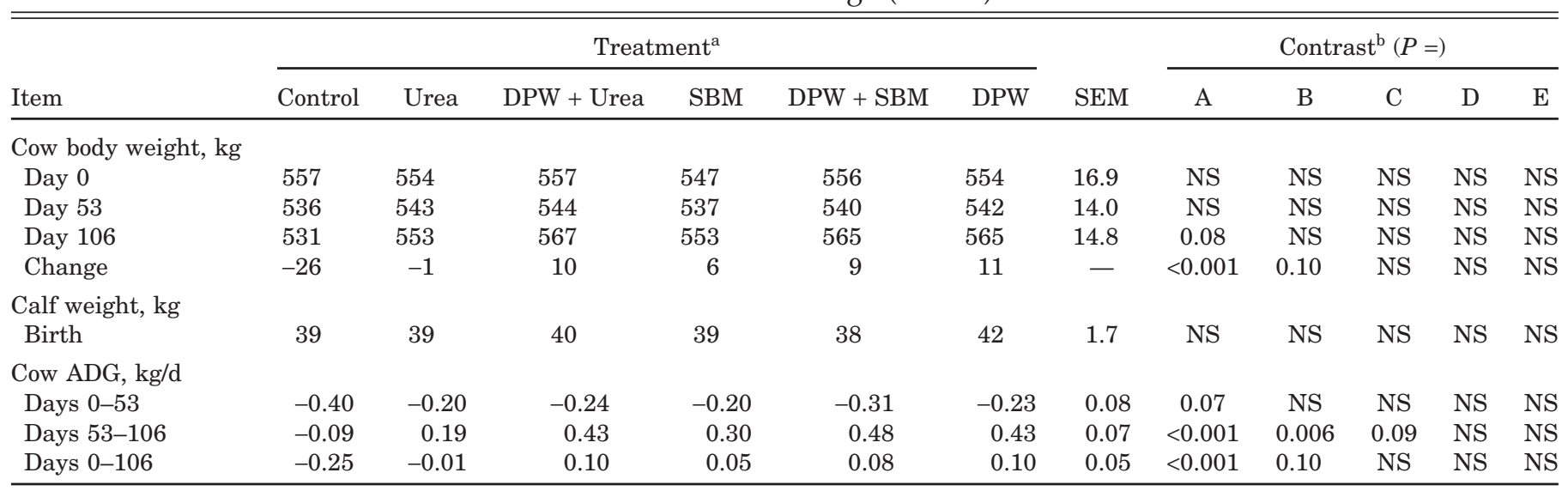

${ }^{a} \mathrm{DPW}=$ dried poultry waste; $\mathrm{SBM}=$ soybean meal.

${ }^{\mathrm{b}}$ Contrasts were A (control vs urea, DPW + urea, SBM, DPW + SBM, DPW), B (urea vs DPW + urea, SBM, DPW + SBM, DPW), C (SBM vs DPW + Urea, DPW + SBM, DPW), D (DPW vs DPW + urea, DPW + SBM $)$ E $(\mathrm{DPW}+$ urea vs DPW + SBM); NS = nonsignificant $(P>0.10)$.

for efficient $\mathrm{N}$ utilization in high-roughage diets. By feeding on alternate days, urea, which is highly soluble in the rumen (Oltjen and Dinius, 1976; Oltjen et al., 1968), would have been immediately available to the microbial population. Oltjen et al. (1968) showed that $1 \mathrm{~h}$ after feeding diets containing similar $\mathrm{N}$ contents, ruminal ammonia concentrations of animals fed urea increased to $58 \mathrm{mg} / 100 \mathrm{~mL}$ of ruminal fluid, whereas ruminal ammonia concentrations in animals fed diets containing uric acid only increased to $15 \mathrm{mg} / 100 \mathrm{~mL}$ of ruminal fluid $7 \mathrm{~h}$ after feeding. Due to the slow rate of forage digestion that was likely experienced by cows in our trial, energy would have been limiting to microbial protein production. Microorganisms would have been dependent on nitrogen recycling by the animal as energy became available, rather than on the urea in the supplement. Oltjen and Dinius (1976) also noted that the average ruminal ammonia concentration for steers fed urea was high (significantly greater compared with other NPN supplements) after $4 \mathrm{~d}$ of supplementation; however, after $28 \mathrm{~d}$, no differences were noted, indicat- ing that ureolytic activity decreased shortly after urea inclusion in the diets. Body condition scores (Table 4) and calf birth weights (Table 3 ) of cows supplemented with urea were similar to those of cows supplemented with natural protein despite the significant depression in ADG.

Compared to SBM, cows consuming supplements containing DPW had similar weight gains, calf birth weights (Table 3), and BCS (Table 4). No differences were found in ADG, calf birth weights (Table 3), or BCS (Table 4) throughout the trial for cows consuming $44 \%$ DPW, 22\% DPW + urea, or 22\% DPW + SBM. These results agree closely with those of Lamm et al. (1977), who found that supplementing cows and heifers grazing corn residues with DPW or SBM resulted in similar gains and calf birth weights. Other researchers have also noted that DPW can be included in forage diets without adverse effects on performance. Smith and Calvert (1976) found that lambs fed a growing diet with DPW or SBM gained similarly. Smith and Wheeler (1979) summarized several trials in which DPW was

Table 4. Body condition score of cows fed different sources of degradable intake protein grazing native Sandhills winter range

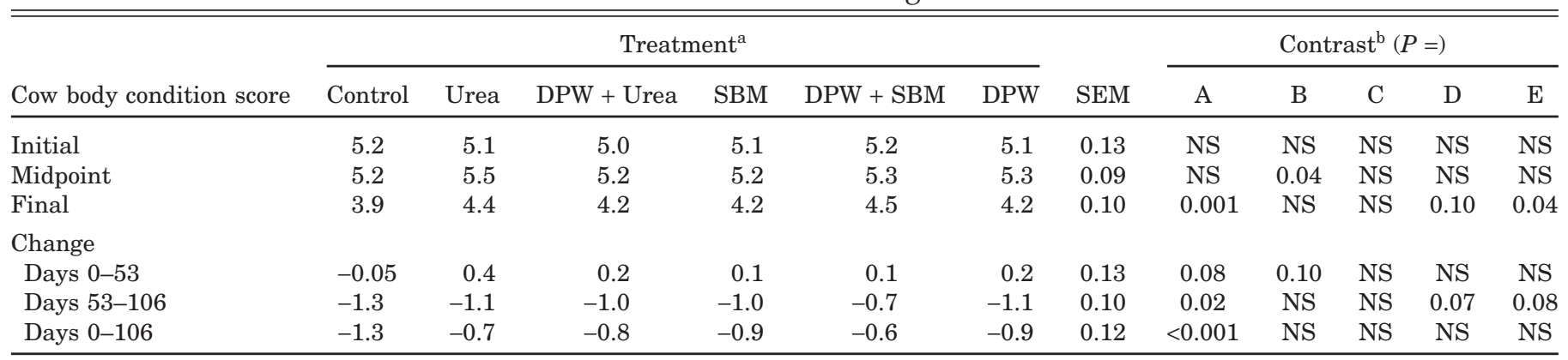

${ }^{\mathrm{a} D P W}=$ dried poultry waste; $\mathrm{SBM}=$ soybean meal.

${ }^{\text {b}}$ Orthogonal contrasts were A (control vs urea, DPW + urea, SBM, DPW + SBM, DPW), B (urea vs DPW + urea, SBM, DPW + SBM, DPW), C (SBM vs DPW + Urea, DPW + SBM, DPW), D (DPW vs DPW + urea, DPW + SBM), E (DPW + urea vs DPW + SBM); NS = nonsignificant $(P>0.10)$. 
Table 5. Daily forage and total organic matter intake of cows fed different sources of degradable intake protein grazing native Sandhills range (Trial 1)

\begin{tabular}{|c|c|c|c|c|c|c|c|c|c|c|c|c|}
\hline Intake, kg/d & \multicolumn{6}{|c|}{ Treatment $^{\mathrm{a}}$} & SEM & \multicolumn{5}{|c|}{ Contrast $^{\mathrm{b}}(P=)$} \\
\hline Forage OM & 13.6 & 13.5 & 12.6 & 13.3 & 12.4 & 12.8 & 0.07 & NS & NS & NS & NS & NS \\
\hline Total OM & 13.6 & 13.8 & 13.0 & 13.6 & 12.8 & 13.1 & 0.07 & NS & NS & NS & NS & NS \\
\hline
\end{tabular}

${ }^{\mathrm{a} D P W}=$ dried poultry waste; $\mathrm{SBM}=$ soybean meal.

${ }^{\mathrm{b}}$ Contrasts were A (control vs urea, DPW + urea, SBM, DPW + SBM, DPW), B (urea vs DPW + urea, SBM, DPW + SBM, DPW), C (SBM vs DPW + Urea, DPW + SBM, DPW), D (DPW vs DPW + urea, DPW + SBM $), \mathrm{E}(\mathrm{DPW}+$ urea vs DPW + SBM $) ; \mathrm{NS}=\mathrm{nonsignificant}(P>0.10)$.

compared with protein from plant sources or NPN. Cattle fed diets containing DPW performed as well as those fed more traditional supplements.

Cows consuming either $22 \% \mathrm{DPW}+$ urea or $22 \% \mathrm{DPW}$ + SBM had similar ADG, calf birth weights (Table 3), and BCS (Table 4). Therefore, if natural protein was required by the microbial population, the DPW and feather meal must have been supplying adequate amounts.

No differences were found in forage organic matter intake (Table 5) or total organic matter intake (Table 5). Based on earlier discussion, the NRC (1996) computer model predicted that the controls were deficient in DIP. However, an intake response to supplementation was not observed. Hollingsworth-Jenkins et al. (1996) and Lamb et al. (1997) also failed to find an intake response in DIP-deficient animals using an acid detergent insoluble nitrogen procedure to predict forage intake when supplementation was accounted for. In all of these studies, $\mathrm{CP}$ of the range diets was 4.5 to $6 \%$. Therefore, the DIP deficiency was relatively small. Conversely, other researchers, such as Köster et al. (1996), have used forages low in $\mathrm{CP}(<2 \%)$ and have obtained sizable $(150 \%)$ increases in digestible organic matter intake. Their increases in intake were relatively small from $6 \%$ $\mathrm{CP}$ to $7 \% \mathrm{CP}$, however.

\section{Trial 2}

All cows lost BW during the study and no BW change differences between DPW and SBM were observed. The BW lost by cows consuming SBM or DPW was 0.28 and $0.28 \mathrm{~kg} / \mathrm{d}$, respectively. That cows lost weight indicates that the corn residue was of a poorer quality than had been observed in previous years. A major determining factor in residue quality (as measured by animal performance) is the amount of corn grain remaining in the field after harvest (Jordon et al., 1997; Irlbeck et al., 1991). Corn grain initially supplies a substantial amount of protein and energy to the cows and accounts for a significant portion of gain. Based on samples collected for other cornstalk grazing trials conducted in 1996-97, little residual corn was available in fields ( $31 \mathrm{~kg} / \mathrm{ha}$; Jordon et al., 1998).

Another likely factor for the BW loss observed in the present trial was inclement weather. When energy requirements become greater than can be met by avail- able forage, animals mobilize body reserves for production of heat. Although the weather was favorable during most of the trial, a relatively severe cold period did occur approximately $2 \mathrm{wk}$ from the end of the trial. The cold weather lasted approximately $10 \mathrm{~d}$ with an average daily temperature of $-12^{\circ} \mathrm{C}$ and an average wind speed of $16 \mathrm{~km} / \mathrm{h}$. This cold period also corresponded to a time when residual grain and forage were most limiting and cows' requirements for fetal growth were increasing. The longer animals remain on the same cornstalk field, the more residue quality declines and residual corn disappears (Gutierrez-Ornelas and Klopfenstein, 1991). Lamm and Ward (1981) noted a decline from 72.0 to $59.2 \%$ in IVOMD in an 86-d grazing trial utilizing mature cows, demonstrating the magnitude of decline that may occur during grazing.

Dried poultry waste was as acceptable to cows as SBM. With the exception of a single animal on the DPW treatment in each trial, the cows readily consumed all supplements. Cows in both Trials 1 and 2 came to the supplements and quickly consumed all cubes from $d 1$ through the end of the trials.

Dried poultry waste with feather meal appears to be a viable SBM substitute for cows on winter range or cows consuming corn residues. Economic analysis of the DPW and SBM supplements indicate the DPW supplement cost $\$ 58$ less per metric ton, which resulted in a savings of $\$ 0.04$ per cow per day and a total savings over $80 \mathrm{~d}$ of $\$ 3.20$ per cow.

\section{Implications}

Winter inputs are the most costly aspect of cow/calf production. Products such as dried poultry waste have the potential to lower wintering costs for beef producers and at the same time to minimize the application of these wastes on the soil. Replacing soybean meal with dried poultry waste and feather meal was effective when supplementing cows grazing either native Sandhills winter range or cornstalks and saved $\$ 55 /$ metric ton in supplement ingredient costs.

\section{Literature Cited}

Adams, D. C., R. E. Short, J. A. Pfister, K. R. Patterson, and D. B. Hudson. 1991. Surgical establishment of esophageal fistula in suckling calves. J. Range Manage. 47:628-629. 
AOAC. 1990. Official Methods of Analysis. 14th ed. Association of Official Analytical Chemists, Washington, DC.

AOAC. 1996. Official Methods of Analysis. 16th ed. Association of Official Analytical Chemists, Arlington, VA.

Bhattacharya, A. N., and J. C. Taylor. 1975. Recycling animal waste as a feedstuff: A review. J. Anim. Sci. 41:1438-1457.

Downs, D. 1997. Diet composition of sandhills winter range and compensatory growth of yearling steers during summer grazing. M. S. thesis, University of Nebraska, Lincoln.

Gutierrez-Ornelas, E., and T. J. Klopfenstein. 1991. Changes in availability and in nutritive value of different corn residue parts as affected by early and late grazing seasons. J. Anim. Sci. 69:1741-1750.

Hollingsworth, K. J., D. C. Adams, T. J. Klopfenstein, J. B. Lamb, and G. Villalobos. 1995. Supplement and forage effects on fecal output estimates from an intra-ruminal marker device. J. Range Manage. 48:137-140.

Hollingsworth-Jenkins, K. J., T. J. Klopfenstein, D. C. Adams, and J. B. Lamb. 1996. Ruminally degradable protein requirement of gestating beef cows grazing native winter sandhills range. J. Anim. Sci. 74:1343-1348.

Irlbeck, N., T. Klopfenstein, M. Sindt, and R. Stock. 1991. Quality and quantity of corn residue on gain of grazing cattle. Nebraska Beef Cattle Rep. MP 56:19-22. Lincoln.

Jordon, D., T. Klopfenstein, J. Brandle, and M. Klemesrud. 1997. Cornstalk grazing in protected and unprotected fields. Nebraska Beef Cattle Rep. MP 67:24-25. Lincoln.

Jordon, D., T. Klopfenstein, and M. Klemesrud. 1998. Evaluation of feather meal for calves grazing cornstalks. Nebraska Beef Cattle Rep. MP 69:40-42. Lincoln.

Karges, K. K. 1990. Effects of rumen degradable and escape protein on cattle response to supplemental protein on native range. M. S. thesis, University of Nebraska, Lincoln.

Köster, H. H., R. C. Cochran, E. C. Titgemeyer, E. S. Vanzant, I. Abdelgadir, and G. St-Jean. 1996. Effect of increasing degradable intake protein on intake and digestion of low- quality, tallgrass-prairie forage by beef cows. J. Anim. Sci. 74:2473-2481.

Lamb, J. B., D. C. Adams, T. J. Klopfenstein, W. W. Stroup, and G. P. Lardy. 1997. Range or meadow regrowth and weaning effects on 2-year-old cows. J. Range Manage. 50:16-19.

Lamm, W. D., and J. K. Ward. 1981. Compositional changes in corn crop residues grazed by gestating beef cows. J. Anim. Sci. 52:954-958.

Lamm, W. D., J. K. Ward, and G. C. White. 1977. Effects of nitrogen supplementation on performance of gestating beef cows and heifers grazing corn crop residues. J. Anim. Sci. 45:1231-1238.
Lardy, G. P. 1997. Protein supplementation of calves and cows grazing Sandhills range and subirrigated meadow. Ph. D. dissertation, University of Nebraska, Lincoln.

Mass, R. A. 1996. Comparison of methods used to determine in situ ruminal protein degradation. J. Anim. Sci. 74(Suppl. 1):288 (Abstr.).

McDougall, E. I. 1948. Studies on ruminant saliva. 1. The composition and output of sheep's saliva. Biochem. J. 43:99-109.

NRC. 1984. Nutrient Requirement of Beef Cattle. 6th ed. National Academic Press, Washington, DC.

NRC. 1996. Nutrient Requirement of Beef Cattle. 7th ed. National Academic Press, Washington, DC.

Oltjen, R. R., and D. A. Dinius. 1976. Processed poultry waste compared with uric acid, sodium urate, urea, and biuret as nitrogen supplements for beef cattle fed forage diets. J. Anim. Sci. 43:201-208.

Oltjen, R. R., L. L. Slyter, A. S. Kozak, and E. E. Williams Jr. 1968. Evaluation of urea, biuret, urea phosphate, and uric acid as NPN sources for cattle. J. Nutr. 94:193-202.

Patterson, H. H., D. C. Adams, and T. J. Klopfenstein. 2000. Supplementation based on the metabolizable protein system versus the crude protein system for primaparous heifers grazing winter range. J. Anim. Sci. 78(Suppl. 2):41 (Abstr.).

Perez, C. J. 1991. Seedbank characteristics of the Nebraska Sandhills Prairie. M. S. thesis, Univ. of Nebraska, Lincoln.

Richards, M. W., J. C. Spitzer, and W. B. Warner. 1986. Effect of varying level of postpartum nutrition and body condition at calving on reproductive performance in beef cattle. J. Anim. Sci. 62:300-306.

Rock, D. W., J. K. Ward, and T. J. Klopfenstein. 1991. Escape protein for beef cows: I. Source and level in corn plant diets. J. Anim. Sci. 69:2282-2288.

Smith, L. W., and C. C. Calvert. 1976. Dehydrated broiler excreta versus soybean meal as nitrogen supplements for sheep. J. Anim. Sci. 43:1286-1292.

Smith, L. W., and W. E. Wheeler. 1979. Nutritional and economic value of animal excreta. J. Anim. Sci. 48:144-156.

Steel, R. G. D., and J. H. Torrie. 1980. Principles and Procedures of Statistics: A Biometrical Approach. McGraw-Hill Publishing Co., New York.

Tilley, J. M. A., and R. A. Terry. 1963. A two-stage technique for the in vitro digestion of forages. J. Br. Grassl. Soc. 18:104-111.

Williams, C. H., D. J. David, and O. Iismaa. 1962. The determination of chromic oxide in faeces samples by atomic absorption spectrophotometry. J. Agric. Sci. 59:381-385. 